\title{
Niche evaluation and evolution path selection of forestry enterprises in Northeast state-owned forest region
}

\author{
Ma X. ${ }^{1,2}$, Geng Y. ${ }^{1 *}$ and Chen X. ${ }^{1}$ \\ ${ }^{1}$ College of Economics and Management, Northeast Forestry University, Harbin 150040, China \\ ${ }^{2}$ College of Management, Heilongjiang University of Science and Technology, Harbin 150022, China \\ Received: 06/07/2020, Accepted: 06/08/2020, Available online: 22/10/2020 \\ *to whom all correspondence should be addressed: e-mail: gydhaerbin@163.com \\ https://doi.org/10.30955/gnj.003400
}

\section{Graphical abstract}

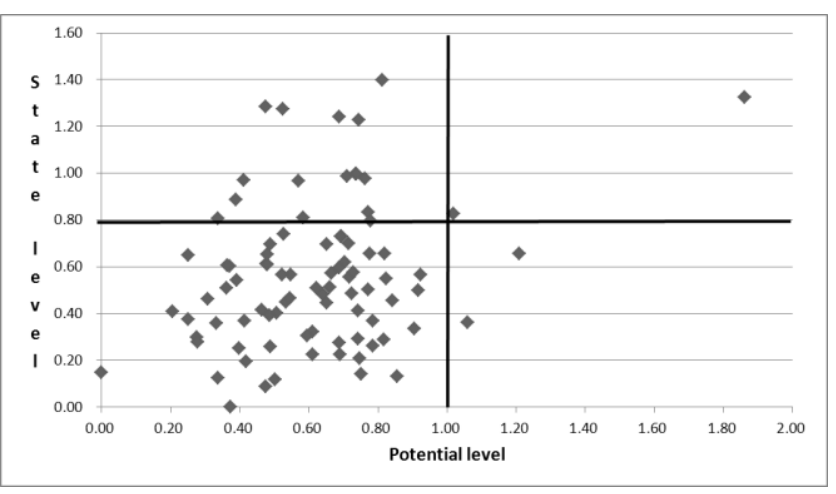

\section{Abstract}

On the Basis of Relevant Theory and Literature Research, analyze the development of forestry enterprises in northeast China, and establish the evaluation index system of the ecological situation of forestry enterprises in northeast China. Based on the composite weights of objective and subjective empowerment, the ecological niche and potential of forestry enterprises in Northeast state-owned forest areas were evaluated and establishes the evaluation index system of the ecological situation of forestry enterprise in northeast China. Based on this, the ecological position and potential of forestry enterprises in the northeast of the northeast are evaluated, and the model of the evolution path selection matrix of the northeast state-owned forest is constructed. Finally, based on the development of ecological path dependence and path breakthrough, passive adaptation and initiative adaptation, the functional ecological selection of forestry enterprises in the northeast state-owned forest sector is combined with the ecological potential of the forestry enterprise, which is the economic benefit priority, ecological benefit and the three main benefits. Based on the basis of the contribution of three different forestry enterprises and the potential value of different forestry enterprises, the corresponding alternative evolution path of the functional ecological evolution of forestry enterprises in the northeast state-owned forest sector is proposed.

Keywords: Ecological niche, situation \& potential, compound weight, evolutionary path.

\section{Introduction}

Northeast State-owned forest area is an important resource producing area and natural ecological levee in China. It has been shouldering the responsibility of national timber production and has made an important contribution to the national economic construction. Northeast stateowned forest industry group has long been taking timber harvesting as its main production and management task. However, due to the limitation of forest resources endowment and the insufficiency of state-owned forest industry management system, the state-owned forest region in Northeast China has gradually presented economic, resource and environmental crises. Since April 1,2014 , the commercial logging of timber has been completely stopped in the Northeast State-owned Forest Area, and forestry enterprises are facing severe economic development and social problems in the forest area. Based on the theory of niche state and potential, combined with the current situation of the development of forestry enterprises in the Northeast State-owned Forest Region, this paper identifies and evaluates the niche state and potential evaluation indexes of forestry enterprises in the Northeast State-owned Forest Region, and then constructs a path selection matrix model. Analyzes and discusses the path selection of forestry enterprises in order to select the evolution path suitable for the forestry enterprises in the Northeast State-owned Forest Region according to the current state and potential of forestry enterprises.

\section{Study on the theory of niche and potential}

There are two main viewpoints in Foreign Studies: Harman and Freeman study from the perspective of enterprise population, and they think that the enterprise niche is the multi-dimensional resource space occupied by the enterprise in the strategic environment; Baum and others describe it from the perspective of enterprise monomer, that is, the enterprise niche is the characteristics of the 
enterprise in the demand and production capacity of the enterprise monomer, which can show the state of the enterprise. The two views of niche are different in research object and purpose, which can be understood as macro niche and micro niche (Guo and Xu, 2009).

According to the theory of niche state and potential put forward by Zhu (1997), any biological unit in the nature has the attributes of "state" and "potential". "State" refers to the state of biological unit, which is the result of growth, development, learning and interaction with the environment in the past; "Potential" refers to the actual dominance or influence of biological units on the environment, such as the rate of energy and material transformation, the rate of biological growth, and the ability to occupy a new environment. Wan (2004) based on the theory of enterprise niche situation, in order to comprehensively evaluate and analyze the development level of enterprises in all aspects, the dimensions of enterprise niche are subdivided, the weight of factors is distributed, and the comprehensive situation evaluation system of enterprise competitiveness is constructed. According to Xuan (2017), the niche of an enterprise reflects the ability of an enterprise to transform its achievements in the industry competition. By analyzing the competitive strength of the niche of an enterprise and comparing the utilization of internal resources of an enterprise, the competitiveness of an enterprise can be evaluated. A.M. Yan with the help of two dimensions of "state" and "potential", the enterprise evaluation index system from the perspective of enterprise niche is formed. In the dimension of "state", it is subdivided into micro factors such as enterprise scale, social influence level and human resource level. In the dimension of "potential", it is subdivided into "potential" factors, which are expressed by the enterprise's organizational management ability, operation ability, technological innovation ability and marketing ability (Yan, 2006). Based on the establishment of the forest eco-economic performance evaluation index system, Li and Zhao (2019) calculated the forest ecoeconomic performance level of the key state-owned forest areas in northeast China and identified its obstacle factors, and showed the evolution stage of the forest eco-economic performance level of the key state-owned forest areas in northeast China. Based on the theory of "state" and "potential" of enterprise niche evaluation, Li (2016) constructed the index system of energy enterprise niche evaluation, conducted comprehensive evaluation on the niche of listed coal mining companies, and then clarified the direction of enterprise ecological strategy selection. Zhang (2016) studied the performance of forest resource management from the perspective of ecological niche and proposed corresponding improvement measures. Jiang (2015) uses AHP to build the management performance evaluation index system of forest farm and obtains the current situation of forest farm management through the analysis of the objectives and contents of forest farm management performance evaluation. Liu (2014) used AHP and other methods to establish the evaluation index system of forest resources and evaluated the performance of forest resources management in state-owned forest farms. Zhang (2014) reviewed the situation of the industrial niche in all stages of the Northeast State-owned Forest Region, identified the ecological niche evolution factors such as resources, demand, technology, policy and system with the situation awareness visualization model, and clarified the synergistic mechanism in the evolution of the forest industrial niche. Geng and Zhang (2014) described the spatial structure and functional structure of the forest industry ecosystem in Heilongjiang state-owned forest area, established the factor model of the forest industry niche, and comprehensively evaluated the evolution power of the forest industry niche in Heilongjiang state-owned forest area. Li (2010) combines the theory of "niche" in ecology with the theory of technology innovation strategy and applies the theory of enterprise niche to solve the problem of technology innovation strategy selection of high-tech enterprises. Shi and Tian (2018) established the evaluation index system of ecological niche situation of green process innovation in home appliance manufacturing industry, proposed the path selection matrix model of green process innovation in home appliance manufacturing industry, and finally determined the path of green process innovation in home appliance manufacturing industry. The empirical results show that compared with the traditional design method of enterprise evaluation model based on financial indicators, this method can comprehensively and systematically reflect the comprehensive situation of the enterprise, and more effectively reflect the survival level and development ability of the enterprise (Haroon et al., 2018; Islam et al., 2020; Suman et al., 2020; Zulkapli et al., 2018).

\section{Development status of forestry enterprises in Northeast state-owned forest region}

The state-owned forest regions in northeast China include Longjiang forest region, Jilin forest region, Changbai mountain forest region and Daxinganling forest region. With the implementation of the natural forest resources protection project and the prohibition of commercial logging, the benefits of forestry enterprises in the northeast state-owned forest regions have decreased obviously. In the northeast state-owned forest region, forestry enterprises not only have a certain social welfare nature, but also take charge of optimizing the regional ecological environment and developing the economy. According to the data of China forestry statistical yearbook 2017, Heilongjiang statistical yearbook, Jilin statistical yearbook and Heilongjiang forest industry comprehensive statistical data collection, the development status of 87 forestry enterprises in northeast state-owned forest regions in 2017 includes the following aspects:

\subsection{Cultivation and protection of forest resources}

The average growth rate of plantation area, restoration area, tending area and seedling area of 87 forestry enterprise samples is $26.68 \%, 30.79 \%, 16.53 \%$ and $81.63 \%$, respectively. All of them are higher than the statistical median, indicating that the overall growth of forest resources cultivation of 87 forestry enterprises is good. 
The standard deviation of the growth rate of artificial afforestation is 1.56 , with a relatively large degree of dispersion; the standard deviation of the growth rate of the restoration area of degraded forest is 1.14 , with a relatively small degree of dispersion; the standard deviation of the growth rate of the tending area of forest is 0.31 , with the smallest degree of dispersion, that is, the difference of the growth rate of the tending area of forest between enterprises is relatively small; the standard deviation of the average growth rate of the nursery area is 2.67 , with the largest degree of dispersion among several indicators. The results show that there are great differences in the growth of seedling area among different forestry enterprises (Asadullah et al., 2018; Eyankware, 2019; Kamel et al., 2018; Mustafa et al., 2019).

\subsection{The production of main products of forestry enterprises} including commodity materials, converted materials and wood-based board
The average growth rate of commodity timber, sawn timber and wood-based panel output of 87 forestry enterprises is - $18.61 \%$, which is seriously lower than the average and all enterprises show zero growth or negative growth, indicating that the production capacity of timber products of forestry enterprises in Northeast State-owned Forest Region is shrinking sharply. Among them, there are 54 enterprises whose output growth rate is higher than the average, accounting for $62.07 \%$, indicating that the distribution of output growth rate of sample enterprises is not uniform. The standard deviation of yield growth rate is 0.24 , and the degree of dispersion is relatively small, which indicates that there is little difference in the yield growth of commercial timber, sawn timber and wood-based panel in different forestry.

Table 1. Ecological Niche Status and Potential Evaluation Index System of Forestry Enterprises in Northeast State-Owned Forest Regions

\begin{tabular}{|c|c|c|c|c|}
\hline $\begin{array}{l}\text { The target } \\
\text { layer }\end{array}$ & $\begin{array}{l}\text { Criterion } \\
\text { layer A }\end{array}$ & Sub criteria layer B & Index layer C & Unit \\
\hline \multirow{22}{*}{ State level } & \multirow{12}{*}{$\begin{array}{c}\text { Economic } \\
\text { performance } \\
\text { A1 }\end{array}$} & $\begin{array}{l}\text { Development of forest } \\
\text { resources B1 }\end{array}$ & $\begin{array}{c}\text { Timber and bamboo picking and } \\
\text { transportation } \mathrm{C} 1\end{array}$ & Ten thousand yuan \\
\hline & & \multirow{3}{*}{$\begin{array}{l}\text { Development of non-forest } \\
\text { resources B2 }\end{array}$} & Economic forest products $\mathrm{C} 2$ & Ten thousand yuan \\
\hline & & & $\begin{array}{l}\text { Flowers and other ornamental plants } \\
\qquad \text { C3 }\end{array}$ & Ten thousand yuan \\
\hline & & & Terrestrial wildlife $\mathrm{C} 4$ & Ten thousand yuan \\
\hline & & \multirow{4}{*}{ Forest Industry B3 } & $\begin{array}{l}\text { Wood processing and manufacturing } \\
\text { C5 }\end{array}$ & Ten thousand yuan \\
\hline & & & Furniture manufacturing C6 & Ten thousand yuan \\
\hline & & & Wooden crafts and stationery $\mathrm{C7}$ & Ten thousand yuan \\
\hline & & & $\begin{array}{l}\text { Processing and manufacturing of non- } \\
\text { wood forest products } \mathrm{C} 8\end{array}$ & Ten thousand yuan \\
\hline & & \multirow{2}{*}{$\begin{array}{l}\text { Forestry production services } \\
\text { and leisure tourism B4 }\end{array}$} & $\begin{array}{l}\text { Forestry tourism and leisure service } \\
\text { C9 }\end{array}$ & Ten thousand yuan \\
\hline & & & Forestry production service C10 & Ten thousand yuan \\
\hline & & $\begin{array}{l}\text { Investment in forestry } \\
\text { industry B5 }\end{array}$ & $\begin{array}{c}\text { Forestry industry development } \\
\text { investment C11 }\end{array}$ & Ten thousand yuan \\
\hline & & Income of employees B6 & $\begin{array}{l}\text { Per capita wage of on-the-job } \\
\text { employees C12 }\end{array}$ & Ten thousand yuan \\
\hline & \multirow{5}{*}{$\begin{array}{l}\text { Ecological } \\
\text { effect A2 }\end{array}$} & \multirow{3}{*}{$\begin{array}{l}\text { Cultivation of forest } \\
\text { resources } B 7\end{array}$} & $\begin{array}{l}\text { Tree breeding and seedling raising } \\
\qquad \text { C13 }\end{array}$ & Ten thousand yuan \\
\hline & & & Afforestation and regeneration C14 & Ten thousand yuan \\
\hline & & & $\begin{array}{c}\text { Forest management, management } \\
\text { and Cultivation C15 }\end{array}$ & Ten thousand yuan \\
\hline & & \multirow{2}{*}{$\begin{array}{l}\text { Forestry ecological } \\
\text { investment B8 }\end{array}$} & $\begin{array}{c}\text { Investment in ecological construction } \\
\text { and protection C16 }\end{array}$ & Ten thousand yuan \\
\hline & & & $\begin{array}{c}\text { Forestry support and guarantee } \\
\text { investment C17 }\end{array}$ & Ten thousand yuan \\
\hline & \multirow{5}{*}{$\begin{array}{l}\text { Social results } \\
\qquad \mathrm{A} 3\end{array}$} & \multirow{3}{*}{ Employment and pension B9 } & Number of employees on duty $\mathrm{C} 18$ & Person time \\
\hline & & & $\begin{array}{l}\text { Number of people who leave the unit } \\
\text { and still maintain labor relations C19 }\end{array}$ & Person time \\
\hline & & & Living expenses of retirees $\mathrm{C} 20$ & Ten thousand yuan \\
\hline & & $\begin{array}{c}\text { Forestry Public Management } \\
\text { and services B10 }\end{array}$ & $\begin{array}{l}\text { Forestry Public Management and } \\
\text { other organizational services C21 }\end{array}$ & Ten thousand yuan \\
\hline & & $\begin{array}{l}\text { Investment in forestry } \\
\text { infrastructure B11 }\end{array}$ & $\begin{array}{l}\text { Investment in forestry infrastructure } \\
\text { construction } \mathrm{C} 22\end{array}$ & Ten thousand yuan \\
\hline
\end{tabular}




\begin{tabular}{|c|c|c|c|c|}
\hline $\begin{array}{l}\text { The target } \\
\text { layer }\end{array}$ & $\begin{array}{l}\text { Criterion } \\
\text { layer A }\end{array}$ & Sub criteria layer B & Index layer C & Unit \\
\hline & \multirow{8}{*}{$\begin{array}{l}\text { Economic } \\
\text { performance } \\
\text { A4 }\end{array}$} & $\begin{array}{l}\text { Production capacity of wood } \\
\text { products B12 }\end{array}$ & $\begin{array}{l}\text { Growth rate of commercial timber, } \\
\text { sawn timber and wood-based panel } \\
\text { production } \mathrm{C} 23\end{array}$ & $\%$ \\
\hline & & \multirow{3}{*}{$\begin{array}{l}\text { Production capacity of non- } \\
\text { wood products B13 }\end{array}$} & $\begin{array}{c}\text { Growth rate of economic forest } \\
\text { products, medicinal materials, fungi } \\
\text { and wild vegetables C24 }\end{array}$ & $\%$ \\
\hline & & & $\begin{array}{c}\text { Growth rate of large livestock and } \\
\text { poultry C25 }\end{array}$ & $\%$ \\
\hline & & & Growth rate of forest tourists $\mathrm{C} 26$ & $\%$ \\
\hline & & $\begin{array}{l}\text { Income growth ability of } \\
\text { employees B14 }\end{array}$ & $\begin{array}{c}\text { Per capita wage growth rate of on- } \\
\text { the-job employees } \mathrm{C} 27\end{array}$ & $\%$ \\
\hline & & $\begin{array}{l}\text { Investment degree of } \\
\text { forestry industry } \\
\text { development B15 } \\
\end{array}$ & $\begin{array}{c}\text { Proportion of forestry industry } \\
\text { development investment in total } \\
\text { investment C28 }\end{array}$ & $\%$ \\
\hline & & \multirow{2}{*}{$\begin{array}{l}\text { Development degree of } \\
\text { output value of non-wood } \\
\text { products and tertiary } \\
\text { industry B16 }\end{array}$} & $\begin{array}{l}\text { Proportion of output value of non- } \\
\text { wood products C29 }\end{array}$ & $\%$ \\
\hline & & & $\begin{array}{l}\text { Proportion of output value of tertiary } \\
\text { industry C30 }\end{array}$ & $\%$ \\
\hline & \multirow{9}{*}{$\begin{array}{l}\text { Ecological } \\
\text { effect A5 }\end{array}$} & $\begin{array}{l}\text { Cultivation degree of forest } \\
\text { resources B17 } \\
\end{array}$ & $\begin{array}{c}\text { Proportion of forest resources } \\
\text { cultivation in total output value C31 }\end{array}$ & $\%$ \\
\hline & & \multirow{2}{*}{$\begin{array}{l}\text { Growth capacity of forestry } \\
\text { ecological investment B18 }\end{array}$} & $\begin{array}{c}\text { Growth rate of investment in } \\
\text { ecological construction and protection } \\
\text { C32 }\end{array}$ & $\%$ \\
\hline & & & $\begin{array}{l}\text { Forestry support and guarantee } \\
\text { investment growth rate C33 }\end{array}$ & $\%$ \\
\hline \multirow[t]{12}{*}{ Potential level } & & \multirow{2}{*}{$\begin{array}{l}\text { Degree of ecological } \\
\text { investment B19 }\end{array}$} & $\begin{array}{c}\text { Proportion of ecological construction } \\
\text { and protection investment in total } \\
\text { investment C34 }\end{array}$ & $\%$ \\
\hline & & & $\begin{array}{c}\text { Proportion of forestry support and } \\
\text { guarantee investment in total } \\
\text { investment C35 }\end{array}$ & $\%$ \\
\hline & & \multirow{4}{*}{$\begin{array}{l}\text { Cultivation capacity of forest } \\
\text { resources B20 }\end{array}$} & Afforestation area growth rate C 36 & $\%$ \\
\hline & & & $\begin{array}{c}\text { Growth rate of restoration area of } \\
\text { degraded forest C37 }\end{array}$ & $\%$ \\
\hline & & & $\begin{array}{l}\text { Growth rate of forest tending area } \\
\text { C38 }\end{array}$ & $\%$ \\
\hline & & & Growth rate of seedling area C39 & $\%$ \\
\hline & \multirow{6}{*}{$\begin{array}{l}\text { Social results } \\
\qquad 66\end{array}$} & \multirow{3}{*}{$\begin{array}{l}\text { Employment and retirement } \\
\text { growth B21 }\end{array}$} & $\begin{array}{l}\text { Growth rate of number of employees } \\
\text { on duty } \mathrm{C} 40\end{array}$ & $\%$ \\
\hline & & & $\begin{array}{c}\text { Growth rate of number of people } \\
\text { leaving the unit } \mathrm{C} 41\end{array}$ & $\%$ \\
\hline & & & $\begin{array}{l}\text { Growth rate of living expenses of } \\
\text { retirees } \mathrm{C} 42 \\
\end{array}$ & $\%$ \\
\hline & & $\begin{array}{l}\text { Investment growth capacity } \\
\text { of forestry infrastructure } \\
\text { B22 }\end{array}$ & $\begin{array}{l}\text { Investment growth rate of forestry } \\
\text { infrastructure construction } \mathrm{C} 43\end{array}$ & $\%$ \\
\hline & & $\begin{array}{c}\text { Investment degree of } \\
\text { forestry infrastructure } \\
\text { construction B23 }\end{array}$ & $\begin{array}{c}\text { Proportion of forestry infrastructure } \\
\text { construction investment in total } \\
\text { investment C44 }\end{array}$ & $\%$ \\
\hline & & $\begin{array}{l}\text { Proportion of forestry public } \\
\text { management and service } \\
\text { B24 }\end{array}$ & $\begin{array}{c}\text { Proportion of forestry public } \\
\text { management and service in total } \\
\text { output value C45 }\end{array}$ & $\%$ \\
\hline
\end{tabular}

\subsection{Production of non-wood products}

The average growth rate of plant products including economic forest products, medicinal materials, fungi and wild vegetables was $58.04 \%$. The average growth rate of livestock and poultry was $70.62 \%$. The average growth rate of the number of forest tourists (person-time) was $172.05 \%$, which was much higher than the median value of $2.25 \%,-5.13 \%$ and $12.9 \%$, indicating that 87 forestry 
enterprises had a strong ability to improve the production of non-wood products.

The standard deviation of growth rate of economic forest products, medicinal materials, fungi and wild vegetable products is 2.6 , and the dispersion degree is relatively the smallest among several indicators, indicating that the production capacity difference of different forestry enterprises in this respect is relatively the smallest. The standard deviation of the growth rate of livestock and poultry was 5.16 , indicating a relatively large dispersion degree. The standard deviation of the growth rate of the number of forest tourists (person-times) is as high as 6.24, and the dispersion degree is the largest among several indicators, indicating that there is a big difference in the development of forest tourism in the enterprise samples.

\subsection{Employees and labor remuneration}

The average growth rate of the number of employees on the job was $-4.66 \%$, and the average growth rate was lower than the median $-3.76 \%$, indicating that the overall size of employees in forestry enterprises was shrinking. The average growth rate of the number of people who leave the unit and still retain labor relations is as high as $64.16 \%$, slightly higher than the median value of $58.51 \%$. The average growth rate of per capita wage of on-the-job employees was $9.02 \%$, slightly higher than the median value of $8.03 \%$, indicating that the overall growth rate of per capita wage of forestry enterprises was slightly better. The growth rate of living expenses for retirees was only 1.12 percent, much lower than the median of 8.25 percent, indicating that the living expenses of retirees in forestry enterprises were gradually relieved.

The standard deviation of the growth rate of the number of on-the-job employees was 0.11 , the smallest dispersion degree among several indicators, indicating that there was little difference in the growth rate of the number of on-thejob employees of various forestry enterprises. The standard deviation of both the growth rate of labor relations and the growth rate of wages per worker are 0.16 , with a relatively larger dispersion degree. The standard deviation of the growth rate of living expenses of retirees is 0.36 , which is the largest discrete degree among several indicators, indicating that the difference degree of the change of living expenses of retirees in different forestry enterprises is relatively higher.

\subsection{Forestry investment completion}

The investment in ecological construction and protection accounted for $87.33 \%$ of the total investment, which was basically consistent with the median of $88.67 \%$. The average proportion of the investment in the development of forestry industry in the total investment is $2.99 \%$, slightly higher than the median. The average proportion of forestry support and guarantee investment in the total amount of completed investment was $1.6 \%$, slightly higher than the median value of $0.49 \%$. Investment in forestry infrastructure construction accounted for $8.07 \%$ of the total amount of total investment, slightly higher than the median $6.7 \%$, indicating that different forestry enterprises have relatively balanced forestry investment.

\subsection{Output value of forestry enterprises}

The primary industry of 87 forestry enterprises accounted for $45.49 \%$ of the total output value on average, among which the output value of wood products of the primary industry accounted for $19.83 \%$, and the output value of non-wood products accounted for $26.11 \%$. The average proportion of the secondary industry in the total output value was $17.36 \%$. The average proportion of the tertiary industry in the total output value is $36.7 \%$, indicating that the output value of the secondary industry of forestry enterprises has decreased while the output value of the tertiary industry and non-wood products is gradually increasing.

\section{Design of state and potential evaluation index system}

4.1. Evaluation index system of ecological status and potential of forestry enterprises in Northeast state-owned forest region

According to the view of ecology, niche includes two basic levels, state and potential, which are interrelated. "state" refers to the state of individual accumulation and occupation of resources. "Potential" is an individual's ability to change and adapt to the environment. The "state" of forestry enterprises in northeast state-owned forest region refers to the original accumulation of forestry enterprises. "Potential" refers to the dominant ability of forestry enterprises to influence the environment. Based on the existing domestic and foreign literatures, this study establishes the niche evaluation index system of forestry enterprises in northeast state-owned forest region from two aspects of niche. According to the evaluation principles of objectivity, practicability, qualitative and quantitative combination, static and dynamic combination, 45 indexes of state and potential attributes were selected to construct the ecological niche and potential evaluation index system of forestry enterprises in northeast state-owned forest regions. Under the two objective levels of state level and potential level, the ecological niche of forestry enterprises in northeast China is evaluated from the three criteria of economic benefit, ecological benefit and social benefit.Under the state forestry enterprise target layer, the economic benefits of rule layer through the forest resources (B1), the development of the forest resources development situation (B2), forest industry (B3), forestry production and leisure travel service (B4), the forestry industry investment situation (B5), the income of employees (B6) six layer is the criterion to measure; The ecological benefit criterion layer is measured by two subcriteria: forest resource cultivation (B7) and forest ecological investment (B8). Social benefits are measured by three sub-criteria: employment and pension (B9), forestry public management and services (B10), and forestry infrastructure investment (B11).

Under the potential target level of forestry enterprises, economic benefits are measured by five sub-criteria: wood product production capacity (B12), non-wood product production capacity (B13), employee income growth capacity (B14), forestry industry development investment 
degree (B15), non-wood product and tertiary industry output value development degree (B16). Ecological benefits were measured by four sub-criteria: forest resources cultivation degree (B17), forestry ecological investment growth ability (B18), ecological investment degree (B19) and forest resources cultivation ability (B20). Social benefits are measured by four sub-criteria: employment and retirement growth (B21), growth capacity of forestry infrastructure investment (B22), investment degree of forestry infrastructure construction (B23), proportion of forestry public management and services (B24). C1-C45 quantifiable indicators were selected under each sub-criterion of state and potential, as shown in Table 1.

Table 2. Objective Weight of Index Obtained by Entropy Weight Method

\begin{tabular}{|c|c|c|c|c|c|c|c|c|}
\hline \multirow{6}{*}{ Index weight at state level $\mathrm{W}_{\mathrm{ei}}$} & $\mathrm{C} 1$ & $\mathrm{C} 2$ & $\mathrm{C} 3$ & $\mathrm{C} 4$ & $\mathrm{C} 5$ & $\mathrm{C} 6$ & $\mathrm{C7}$ & $\mathrm{C} 8$ \\
\hline & 0.027 & 0.051 & 0.008 & 0.031 & 0.044 & 0.017 & 0.031 & 0.027 \\
\hline & C9 & C10 & C11 & C12 & C13 & C14 & C15 & C16 \\
\hline & 0.045 & 0.048 & 0.024 & 0.072 & 0.042 & 0.047 & 0.078 & 0.061 \\
\hline & $\mathrm{C} 17$ & $\mathrm{C} 18$ & C19 & $\mathrm{C} 20$ & $\mathrm{C} 21$ & $\mathrm{C} 22$ & & \\
\hline & 0.055 & 0.059 & 0.074 & 0.059 & 0.046 & 0.056 & & \\
\hline \multirow{6}{*}{ Index weight at potential level $\mathrm{w}_{\mathrm{ei}}$} & $\mathrm{C} 23$ & $\mathrm{C} 24$ & $\mathrm{C} 25$ & $\mathrm{C} 26$ & $\mathrm{C} 27$ & $\mathrm{C} 28$ & $\mathrm{C} 29$ & C30 \\
\hline & 0.049 & 0.036 & 0.035 & 0.038 & 0.066 & 0.040 & 0.045 & 0.048 \\
\hline & C31 & C32 & C33 & C34 & C35 & C36 & C37 & C38 \\
\hline & 0.046 & 0.041 & 0.034 & 0.052 & 0.044 & 0.039 & 0.040 & 0.042 \\
\hline & C39 & $\mathrm{C} 40$ & C41 & $\mathrm{C} 42$ & C43 & $\mathrm{C} 44$ & $\mathrm{C} 45$ & \\
\hline & 0.039 & 0.046 & 0.050 & 0.053 & 0.033 & 0.045 & 0.043 & \\
\hline
\end{tabular}

Table 3. Subjective Weight of Indicators Obtained by AHP

\begin{tabular}{|c|c|c|c|c|c|c|c|c|}
\hline \multirow{6}{*}{ Index weight at state level $\mathrm{W}_{\mathrm{ai}}$} & C01 & $\mathrm{CO} 2$ & $\mathrm{CO3}$ & $\mathrm{CO} 4$ & $\mathrm{CO5}$ & C06 & $\mathrm{CO}$ & $\mathrm{CO} 8$ \\
\hline & 0.040 & 0.043 & 0.008 & 0.019 & 0.017 & 0.011 & 0.013 & 0.035 \\
\hline & C09 & C10 & C11 & C12 & C13 & C14 & C15 & C16 \\
\hline & 0.014 & 0.003 & 0.021 & 0.073 & 0.059 & 0.107 & 0.194 & 0.060 \\
\hline & $\mathrm{C} 17$ & $\mathrm{C} 18$ & C19 & $\mathrm{C} 20$ & $\mathrm{C} 21$ & $\mathrm{C} 22$ & & \\
\hline & 0.120 & 0.016 & 0.004 & 0.006 & 0.041 & 0.097 & & \\
\hline \multirow{6}{*}{ Index weight at potential level $\mathrm{W}_{\mathrm{ai}}$} & $\mathrm{C} 23$ & $\mathrm{C} 24$ & $\mathrm{C} 25$ & $\mathrm{C} 26$ & $\mathrm{C} 27$ & $\mathrm{C} 28$ & C29 & C30 \\
\hline & 0.119 & 0.023 & 0.005 & 0.013 & 0.063 & 0.057 & 0.006 & 0.012 \\
\hline & C31 & C32 & C33 & C34 & C35 & C36 & C37 & C38 \\
\hline & 0.069 & 0.086 & 0.172 & 0.050 & 0.025 & 0.055 & 0.038 & 0.023 \\
\hline & C39 & $\mathrm{C} 40$ & $\mathrm{C} 41$ & $\mathrm{C} 42$ & $\mathrm{C} 43$ & $\mathrm{C} 44$ & $\mathrm{C} 45$ & \\
\hline & 0.023 & 0.024 & 0.005 & 0.009 & 0.016 & 0.077 & 0.032 & \\
\hline
\end{tabular}

\subsection{Data sources and standardized processing}

In order to comprehensively, truly and accurately reflect the ecological niche of forestry enterprises in the Northeast State-owned Forest Area, the data used in the analysis are all from the statistical data such as China forestry statistical yearbook, Heilongjiang statistical yearbook, Jilin statistical yearbook and Heilongjiang forest industry comprehensive statistical data collection between 2016 and 2017. The Zscore method is used for standardization, which divides the result of subtracting the single number from the mean value of the set by the standard deviation of the set to get the standardized result. This method is similar to the standardized transformation of normal distribution, and the transformation function is as follows:

$$
Z=\frac{(x-\mu)}{\sigma}
$$

$Z$ is the standard value, $x$ is the original value that needs to be standardized, $\mu$ is the mean, $\sigma$ is the standard deviation, and $\sigma \neq 0$. Most of the 45 indicators are positive indicators, but $\mathrm{C} 19$ and C41, which reflect social benefits, are obviously reverse indicators. Therefore, it is necessary to use the formula of range transformation method to process the reverse indicators.

$$
A_{i j}=\frac{\max \left(Z_{i j}\right)-Z_{i j}}{\max \left(Z_{i j}\right)-\min \left(Z_{i j}\right)}
$$

$A_{i j}$ is the inverse index positive value, $Z_{i j}$ is the enterprise index standardized value, $\max \left(Z_{i j}\right)$ and $\min \left(Z_{i j}\right)$ respectively represent the maximum and minimum value of $i$ indicators.

\section{Obtaining composite weight set of evaluation index}

\subsection{Obtaining objective weight of evaluation index by} entropy weight method

Firstly, the entropy weight coefficient method is adopted to calculate the objective weight of each index. It needs a certain amount of sample data to support, and the calculation process is relatively simple and the analysis principle is intuitive. First, calculate the entropy value according to the standardized data:

$$
e_{i}=\frac{\sum_{j=1}^{n} x_{i j} \square n x_{i j}}{\ln n}
$$

$e_{i}$ is the entropy value of the ith initial evaluation index $x_{i j}$. If the entropy value of an index is smaller, it means that the 
variation degree of its index value is larger, the information provided is larger, and it plays a bigger role in the evaluation, so its weight is also larger. Otherwise, the weight is smaller. Finally, the results of calculating the index entropy weight are shown in Table 2.

$$
w_{i}=\frac{1-e_{i}}{\sum_{i=1}^{n}\left(1-e_{i}\right)}
$$

where, $w_{i}$ is the entropy weight of $x_{i j}, 0 \leq w_{i} \leq 1$ and $\sum_{i=1}^{n} w_{i}=1$.

\subsection{The subjective weight of evaluation index is obtained by $A H P$}

\subsubsection{Construct judgment matrix}

Table 4. Obtaining Composite Weight of Evaluation Index by Minimum Entropy Principle

Index weight at state level $\mathbf{w}_{\mathrm{i}}$

\begin{tabular}{|c|c|c|c|c|c|c|c|c|}
\hline \multirow{6}{*}{ Index weight at state level $w_{i}$} & $\mathrm{C} 01$ & $\mathrm{CO2}$ & $\mathrm{CO3}$ & $\mathrm{CO4}$ & $\mathrm{CO5}$ & C06 & $\mathrm{CO7}$ & $\mathrm{CO8}$ \\
\hline & 0.036 & 0.052 & 0.009 & 0.027 & 0.031 & 0.015 & 0.022 & 0.034 \\
\hline & C09 & C10 & C11 & C12 & C13 & C14 & C15 & $\mathrm{C} 16$ \\
\hline & 0.027 & 0.013 & 0.024 & 0.081 & 0.055 & 0.079 & 0.136 & 0.067 \\
\hline & C17 & C18 & C19 & $\mathrm{C} 20$ & $\mathrm{C} 21$ & $\mathrm{C} 22$ & & \\
\hline & 0.090 & 0.034 & 0.018 & 0.021 & 0.048 & 0.082 & & \\
\hline \multirow{6}{*}{ Index weight at potential level $w_{i}$} & $\mathrm{C} 23$ & $\mathrm{C} 24$ & $\mathrm{C} 25$ & $\mathrm{C} 26$ & $\mathrm{C} 27$ & $\mathrm{C} 28$ & C29 & $\mathrm{C} 30$ \\
\hline & 0.084 & 0.032 & 0.014 & 0.024 & 0.071 & 0.053 & 0.018 & 0.026 \\
\hline & C31 & C32 & C33 & C34 & C35 & C36 & C37 & C38 \\
\hline & 0.062 & 0.066 & 0.085 & 0.056 & 0.036 & 0.051 & 0.044 & 0.034 \\
\hline & C39 & $\mathrm{C} 40$ & C41 & C42 & $\mathrm{C} 43$ & C44 & $\mathrm{C} 45$ & \\
\hline & 0.033 & 0.037 & 0.018 & 0.024 & 0.025 & 0.065 & 0.041 & \\
\hline
\end{tabular}

Table 5. List of Niche Values of Forestry Enterprises in Northeast State-Owned Forest Region

Index weight at potential level $\mathrm{w}_{\mathrm{i}}$

Through the analysis of the system, the evaluation index system of hierarchical structure is constructed. According to the evaluation criteria of the upper layer, the relative importance of two indicators in the lower layer is compared, and the judgment matrix is established. The judgment matrix of ecological niche AHP to obtain the subjective weight of the index was constructed by consulting forest-related experts and professors with the method of 9 proportional scale.

$W_{T}$ represents the judgment matrix of $A 1, A 2$ and $A 3$ indexes relative to the target level of the state level, while $W_{s}$ represents the judgment matrix of $A 4, A 5$ and $A 6$ indexes relative to the target level of the potential level. $W_{B 1}$ represents the judgment matrix of indicators $B 1, B 2$, $B 3, B 4, B 5$ and $B 6$ relative to superior indicator $A 1 \ldots ; W_{C 1}$ represents the judgment matrix of $\mathrm{C} 1, \mathrm{C} 2$ and $\mathrm{C} 3$ indicators relative to their superior indicator $\mathrm{B} 1$.

\begin{tabular}{|c|c|c|c|c|c|c|c|}
\hline Aershan & Zuoer & Chuoyuan & Wuerqihan & Kuduer & Tulihe & Yitulihe & Keyihe \\
\hline 3.42 & 3.59 & 3.31 & 3.56 & 3.64 & 3.54 & 3.36 & 3.45 \\
\hline Ganhe & Jiwen & Alihe & Genhe & Jinhe & Alongshan & Mangui & Deerbuer \\
\hline 3.59 & 3.45 & 3.59 & 4.08 & 3.58 & 3.49 & 3.66 & 3.53 \\
\hline Moerdaoga & Dayangshu & Bilahe & Linjiang & Sanchazi & Wangou & Songjianghe & Quanyang \\
\hline 3.91 & 3.22 & 3.21 & 4.48 & 4.36 & 3.48 & 3.53 & 3.37 \\
\hline Lushuihe & Baishishan & Hongshi & Huangnihe & Dunhua & Dashitou & Bajiazi & Helong \\
\hline 3.55 & 3.65 & 3.70 & 3.40 & 3.89 & 3.65 & 3.63 & 3.91 \\
\hline Wangqing & Daxinggou & Tianqiaoling & Baihe & Hunchun & Dahailin & Chaihe & Dongjingcheng \\
\hline 3.74 & 3.34 & 3.39 & 4.41 & 3.74 & 3.59 & 3.82 & 3.81 \\
\hline Muling & Suiyang & Hailin & Linkou & Bamiantong & Huanan & Shuangyashan & Heli \\
\hline 3.89 & 4.37 & 3.69 & 3.78 & 3.37 & 3.34 & 3.08 & 3.17 \\
\hline Hebei & Dongfanghong & Yingchun & Qinghe & Shuangfeng & Tieli & Taoshan & Langxiang \\
\hline 3.46 & 3.97 & 3.28 & 3.69 & 3.21 & 3.65 & 3.45 & 3.49 \\
\hline Nancha & Jinshantun & Meixi & Wumahe & Cuiluan & Youhao & Shangganling & Wuying \\
\hline 3.47 & 3.31 & 3.69 & 3.38 & 3.36 & 3.73 & 3.29 & 3.81 \\
\hline Hongxing & Xinqing & Tangwanghe & Wuyiling & Shanhetun & Weihe & Yabuli & Fangzheng \\
\hline 3.23 & 3.69 & 3.54 & 3.20 & 3.68 & 3.65 & 3.78 & 3.74 \\
\hline Xinglong & Suiling & Tongbei & Zhanhe & Dailing & Songling & Xinlin & Tahe \\
\hline 3.44 & 3.50 & 3.34 & 4.05 & 3.63 & 4.07 & 4.31 & 4.32 \\
\hline Huzhong & Amuer & Tuqiang & Xilinji & Shibazhan & Hanjiayuan & Jiagedaqi & \\
\hline 4.08 & 3.78 & 3.74 & 4.05 & 3.57 & 4.06 & 3.88 & \\
\hline
\end{tabular}

\subsubsection{Weight calculation}

Find the maximum eigenvalue $\lambda_{\max }$ of the judgment matrix, and the corresponding eigenvector is $W\left(w_{1}, w_{2} \ldots, w_{m}\right)$, classified the importance of the judgment of the previous layer, and obtained the weight value of the feature vector w. 


\subsubsection{Conformance test}

Due to the complexity and randomness of the system, the judgment matrix of the expert consulting method may not be consistent, and the judgment matrix must be tested to maintain consistency. The test formula is:

$$
C R=\frac{C l}{R I}=\frac{\lambda_{\max }-m}{(m-1) R I}
$$

In the formula, $\mathrm{Cl}$ represents the consistency index, $m$ is the order, $C R$ is the random consistency ratio, and the judgment matrix $C R$ is all less than 0.1 , indicating that the weight is reasonable and the consistency is good. The final subjective weight of the evaluation index is shown in Table 3.

\subsection{Obtaining composite weight of evaluation index by} minimum entropy principle

In the process of comprehensive evaluation, the value of index weight will affect the rationality of the evaluation

Table 6. List of Ecological Potential Value of Forestry Enterprises in Northeast State-Owned Forest Region

\begin{tabular}{|c|c|c|c|c|c|c|c|}
\hline Aershan & Zuoer & Chuoyuan & Wuerqihan & Kuduer & Tulihe & Yitulihe & Keyihe \\
\hline 6.49 & 6.35 & 6.27 & 6.22 & 6.30 & 6.42 & 6.27 & 6.64 \\
\hline Ganhe & Jiwen & Alihe & Genhe & Jinhe & Alongshan & Mangui & Deerbuer \\
\hline 6.24 & 6.37 & 6.20 & 6.32 & 6.50 & 6.33 & 6.31 & 6.23 \\
\hline Moerdaoga & Dayangshu & Bilahe & Linjiang & Sanchazi & Wangou & Songjianghe & Quanyang \\
\hline 6.35 & 6.33 & 6.44 & 6.39 & 6.11 & 6.09 & 6.12 & 6.32 \\
\hline Lushuihe & Baishishan & Hongshi & Huangnihe & Dunhua & Dashitou & Bajiazi & Helong \\
\hline 6.13 & 6.25 & 6.28 & 6.19 & 6.17 & 6.51 & 6.41 & 6.60 \\
\hline Wangqing & Daxinggou & Tianqiaoling & Baihe & Hunchun & Dahailin & Chaihe & Dongjingcheng \\
\hline 6.79 & 6.37 & 6.18 & 7.44 & 6.40 & 5.94 & 6.11 & 6.28 \\
\hline Muling & Suiyang & Hailin & Linkou & Bamiantong & Huanan & Shuangyashan & Heli \\
\hline 5.92 & 6.06 & 5.95 & 6.30 & 6.40 & 5.98 & 5.95 & 6.06 \\
\hline Hebei & Dongfanghong & Yingchun & Qinghe & Shuangfeng & Tieli & Taoshan & Langxiang \\
\hline 5.83 & 5.97 & 6.00 & 5.95 & 5.92 & 6.13 & 5.99 & 5.79 \\
\hline Nancha & Jinshantun & Meixi & Wumahe & Cuiluan & Youhao & Shangganling & Wuying \\
\hline 6.07 & 6.19 & 6.06 & 5.86 & 5.86 & 5.83 & 6.33 & 6.27 \\
\hline Hongxing & Xinqing & Tangwanghe & Wuyiling & Shanhetun & Weihe & Yabuli & Fangzheng \\
\hline 5.58 & 6.06 & 5.89 & 6.08 & 6.27 & 6.10 & 6.07 & 6.06 \\
\hline Xinglong & Suiling & Tongbei & Zhanhe & Dailing & Songling & Xinlin & Tahe \\
\hline 5.91 & 6.05 & 6.07 & 5.99 & 5.97 & 6.29 & 6.33 & 6.27 \\
\hline Huzhong & Amuer & Tuqiang & Xilinji & Shibazhan & Hanjiayuan & Jiagedaqi & \\
\hline 6.32 & 6.23 & 6.36 & 6.15 & 6.31 & 6.35 & 6.36 & \\
\hline
\end{tabular}

5.4. Evaluation results of ecological position and potential of forestry enterprises in Northeast State-owned Forest region

In order to quantitatively calculate the niche status and potential level of forestry enterprises in the northeast state-owned forest region, it is necessary to conduct standardized processing on the index data. Through formula (7) and formula (8), the comprehensive evaluation value of ecological niche level and potential level indexes of different forestry enterprises can be obtained, namely the os and op values of each forestry enterprise.

$$
\mathrm{OS}_{j}=\sum_{i=1}^{22} w_{i} \times A_{i j}
$$

result. The objective weight of entropy weight assignment reflects the difference between the measured values of each index. AHP is used to calculate the subjective weight of indicators to reflect the relative importance of each indicator. Therefore, by integrating subjective weight and objective weight, the minimum entropy principle can obtain the composite weight of evaluation index.

$$
w_{i}=\frac{\sqrt{w_{e i} \times w_{a i}}}{\sum_{i=1}^{n} \sqrt{w_{e i} \times w_{a i}}}
$$

In the formula, $w_{i}$ is compound weight, $w_{e i}$ and $w_{a i}$ are objective weight and subjective weight respectively, and $n$ is the number of indicators in the evaluation sample. The Lagrange multiplier method is used to optimize the composite weight, and the final composite weight of the evaluation index is obtained as shown in Table 4. 


\section{Evolution path selection}

\subsection{Construction of niche evolution path selection matrix model for forestry enterprises}

Based on the above for the northeast forestry enterprises of state-owned forest ecological niche, the analysis on the level of potential, according to the different forestry enterprise niche and potential evaluation result, constructs the northeast state-owned forest ecological niche evolution route choice matrix model, and make the different forestry enterprises according to their own niche status, choose suitable evolution path, as shown in Figure 1.

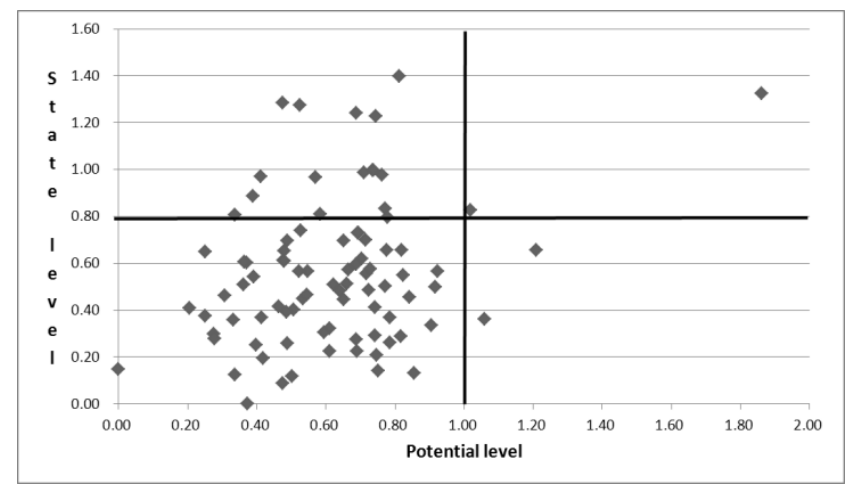

Figure 1. Matrix model of niche evolution path selection for forestry enterprises in northeast state-owned forest region

The vertical axis of Figure 1 shows the evaluation value of niche status of forestry enterprises in the northeast stateowned forest region, that is, the power of resource possession under certain conditions. The horizontal axis shows the evaluation value of ecological potential, indicating the actual influence and dominant position of enterprises on the surrounding environment under certain conditions. When the evaluation value is 0 , the ability is the lowest. Along with the improvement of the evaluation value of the horizontal and vertical coordinate, it indicates that the forestry enterprise's ability of resource occupation and environmental control and utilization is enhanced. The 87 scatter points in Figure 1 respectively represent the niche status and potential position of 87 forestry enterprises in the northeast state-owned forest region. In order to enhance the scatter visual effect, the data of the scatter diagram is translated, with the horizontal axis being translated by 5.58 to the left and the vertical axis being translated by 3.08 to the down.

6.2. The selection mode of niche evolution path of forestry enterprises in Northeast state-owned forest region

\subsubsection{Niche path dependence and path breakthrough evolution of forestry enterprises}

Niche path dependence of forestry enterprises refers to the path locked in existing resources, needs, technologies, policies and systems due to accidental or random events in the early development of forestry enterprises, and the locked path may be positive or negative. The positive pathdependent effect can form the continuous growth of forestry enterprise niche, and the intensified effect of resources and technology can promote the sustainable development of forestry enterprise niche. As shown in Figure 1, the accumulation of resources, technologies, markets, capital and other conventions formed over A long period of time has played $A$ beneficial role in promoting the forestry enterprises with high state values in area $A$ and area $B$, forming $A$ virtuous circle. The path dependence effect with negative feedback forms irreversibility, and its evolution direction continues to develop towards deeper and lower efficiency, entering a vicious circle. State as shown in Figure $1 C$ and $D$ area value lower forestry enterprises, in the early stages of state-owned forestry enterprise development, excessive use of forest resources, forest product demand of single and forestry industrial policy and the lack of market mechanism, and makes some forestry enterprise niche evolution locking traditional forestry development path, as the primitive accumulation of resources reduce the formation of the low efficiency of path dependence effect. However, path breakthrough evolution is the creative destruction of the original path through conscious transformation or external forces and the establishment of a new evolutionary path to eliminate negative feedback mechanism.

\subsubsection{Passive adaptation and active adaptation evolution of forest enterprise niche}

The production and management of forestry enterprises is a process of dynamic adaptation and passive adaptation, including two-way adaptation to the environment and transformation. Any production and operation activities of forestry enterprises should passively accept the natural selection of environment and formulate the adaptive strategy in line with the environment of forestry enterprises. Active adaptation is the biggest difference between niche evolution and natural niche evolution of forestry enterprises. In the process of active adaptation evolution, forestry enterprises continue to enhance their ability to transform the industrial environment and enhance their active adaptability to the industrial environment. The evolution of forest enterprise niche initiative adaptation is reflected in the ability of enterprise to improve individual change and adapt to the environment, such as the rate of energy and material exchange, growth rate, economic growth rate, etc. As shown in Figure 1, the potential values of zone $B$ and Zone $D$ are low, indicating that the ability of enterprises in the region to transform and adapt to the environment is low, while the potential values of zone a and Zone $\mathrm{C}$ are high, indicating that these forestry enterprises have certain influence on the current and future environment. The evolution of forestry enterprises' initiative adaptation plays a decisive role in the future development direction of enterprises.

Combined with the functional ecological selection of forestry enterprises in the Northeast State-owned Forest Region, it has three advantages: economic interest priority, ecological interest priority and ecological niche of forestry enterprises. Based on the contribution degree of three benefit States and potential values of different forestry 
enterprises, the paper puts forward the corresponding alternative evolution path for the functional niche evolution of forestry enterprises in the Northeast Stateowned Forest Region.

\subsection{Description of each region of selection matrix model and case analysis of forestry enterprises}

The selection matrix model is equally divided into four quadrants, and according to different states and potential positions, the idea of choosing the evolutionary path of forestry enterprises in northeast state-owned forest region is put forward.

\subsubsection{Ecological niche status and potential evaluation are in area $A$}

There are only two forestry enterprises in area a, accounting for only $2.3 \%$. Area a shows that the forestry enterprises are in the excellent state of "state" and "potential", and the enterprises have reached a higher capacity in the environment conducive to their own development. Therefore, the forestry enterprises in this area are the best ecological niche, and the locked path has a positive impact on the enterprises. In the long-term development of production and management, forestry enterprises have accumulated certain capacity in all aspects. In the further development, forestry enterprises should analyze and integrate the existing resources to realize the coordinated realization of economic benefits, ecological benefits and social benefits.

Taking Baihe as an example, the state and potential values of the enterprise are relatively high (1.32 and 1.86, respectively), indicating that the locked path dependence is conducive to better matching of resources and capabilities. The economic benefit, ecological benefit and social benefit of the state value are $0.46,0.56$ and 0.3 . The three benefits of potential value are $0.51,0.98$ and 0.37 respectively. It can be seen that the ecological benefits of Baihe are the most advantageous in terms of state and potential. So the "path dependence - priority of ecological benefits" niche evolution is the appropriate choice of Baihe niche evolution.

\subsubsection{Ecological niche status and potential evaluation are in area $B$}

There are 14 forestry enterprises with evaluation value in area $\mathrm{B}$, accounting for $16.1 \%$. The forestry industry environment has a certain positive impact on these forestry enterprises. The environment and resources can promote the good development of enterprises. Enterprises have rich resources in a broader ecological niche environment. However, the limited potential of forestry enterprises shows the weak development ability and the low level of control and control over the environment.

Taking Xinlin as an example, the higher state value and the lower potential value of enterprises are 1.23 and 0.74 respectively, which indicates that enterprises have good original accumulation but general control ability. Therefore, they should establish their own characteristics, actively enhance their ability to adapt and transform the environment and form a competitive advantage. The economic benefit, ecological benefit and social benefit of state value are $0.42,0.56,0.25$; the three benefits of potential value are $0.24,0.35,0.15$, respectively. It can be seen that Xinlin has great advantages in the development of ecological benefit in state and potential. Therefore, the niche evolution of "initiative adaptation - ecological benefit priority" is a reasonable choice for Xinlin niche evolution.

\subsubsection{Ecological niche status and potential evaluation are in area $C$}

There are two forestry enterprises in area $\mathrm{C}$, accounting for only $2.3 \%$. These enterprises occupy a narrow niche, occupy relatively less resources, and threaten the development of enterprises. But at the same time, the enterprise has high potential. At this time, the enterprise should break away from the environmental constraints as soon as possible, actively expand the potential niche, and break through the current negative feedback path dependence.

Taking Wangqing as an example, the low state value and high potential value of the enterprise are 0.66 and 1.21 respectively, indicating that the enterprise has strong capability but worrying resources and environment, so it should actively explore the potential ecological niche. The score of economic benefit, ecological benefit and social benefit is $0.24,0.27$ and 0.15 . The three major benefits of potential value are $0.41,0.55$ and 0.24 , respectively. It can be seen that the development advantages of ecological benefits in the state and potential of Wangqing are relatively large. So "path breakthrough - ecological benefit priority" niche evolution is ++ niche evolution appropriate choice.

\subsubsection{Ecological niche status and potential evaluation are in area $D$}

There are 69 forestry enterprises in the $D$ region, accounting for $79.34 \%$ of the total, accounting for the majority of state-owned forestry enterprises in Northeast China. The potential of forestry enterprises in this position is not only small, but also the environment is very unfavorable to them. Therefore, on the one hand, forestry enterprises should get rid of the original path lock, break the negative cycle to achieve path breakthrough, on the other hand, they need to strengthen their ability to adapt to the environment and transform the environment.

Taking Wumahe as an example, the enterprise state value and potential value are relatively low, 0.3 and 0.28 respectively, indicating that the enterprise capacity and environmental resources are poor. The economic benefit, ecological benefit and social benefit of state value are 0.11 , $0.12,0.06$; the three benefits of potential value are 0.09 , $0.13,0.06$, respectively. It can be seen that the development advantage of state and potential ecological benefit of Wumahe is relatively large. Therefore, "path breakthrough initiative adaptation ecological benefit priority" niche evolution is a more reasonable choice for Wumahe niche evolution at present. 


\section{Conclusion}

On the basis of niche theory, a niche status and potential evaluation index system for forestry enterprises in northeast state-owned forest region was established, and the niche status and potential values of 87 forest enterprise samples in northeast state-owned forest region were calculated by using entropy method, analytic hierarchy process and compound weighting method. On the basis of constructing the matrix model of evolution path selection, the feasible evolution path is established for the corresponding forestry enterprises according to different quadrants. It is expected to provide qualitative and quantitative support for the study of niche evolution path of forestry enterprises in northeast state-owned forest regions, so as to promote the development of forestry enterprises and play a positive role in guiding the strategic positioning and operation of forestry enterprises in northeast state-owned forest regions.

\section{Acknowledgments}

This study is supported by the Project of Research and Planning Fund for Humanities and Social Sciences of the Ministry of Education (No. 17yja630094) "Research on the Transformation Mode and Path of Forestry Industry in Northeast State-owned Forest Region Based on Industrial Ecosystem"; and the Fund Project of State Forestry Administration (No. jyc2016-47) "Research on Problems and Countermeasures of State-owned Forest Reform".

\section{References}

Asadullah N., Faizan A. and Farva K. (2018), Evaluation of Low Cost Environment Friendly Natural Extracts For The Purification Of Drinking Water, Earth Sciences Pakistan, 2(1), 23-25.

Eyankware M.O. (2019), Hydrogeochemical Assessment Of Chemical Composition Of Groundwater; A Case Study Of The Aptian-Albian Aquifer Within Sedimentary Basin (Nigeria), Water Conservation and Management, 3(1), 01-07.

Geng Y.D. and Zhang C.H. (2014), Study on the evolution mechanism and dynamic evaluation of forestry industry niche in Heilongjiang state-owned forest region, Forestry Economy, 36(02), 98-104.

Guo Y. and Xu X.Y. (2009), A review of the research on enterprise niche: Concept, measurement and strategic application, Industrial Economic Review, 8(02): 105-119.

Haroon R., Ch A. and Shahbaz N.K. (2018), Wastewater Irrigation, Its Impact On Environment And Health Risk Assessment In Peri Urban Areas Of Punjab Pakistan - A Review. Environmental Contaminants Reviews, 1(1), 30-35.

Islam M.A., Islam S.M.A. and Sathi M.A. (2020), Identification Of Lentil Varieties/Lines Resistant To Stemphylium Blight Considering Disease Reaction And Yield, Malaysian Journal of Sustainable Agriculture, 4(1), 22-25.

Jiang J. (2015), Research on performance evaluation of Jindong Forest Farm Based on AHP. Central South University of Forestry Science and Technology.

Kamel K., Bachir S. and Robert A. (2018), Variation in Sediment Concentration and Water Disharge During Storm Events in Two Catchments, Northeast of Algeria. Earth Sciences Malaysia, 2(2), 01-09.

Li C.H. and Zhao X.H. (2019), Forest economic performance evaluation and obstacle factor diagnosis of key state-owned forest areas in Northeast China. World Forestry Research, 32(1), 105-109.

Li J.C. (2010), Research on technology innovation strategy selection of high-tech enterprises based on enterprise niche. Harbin Engineering University.

Li L. (2016), Niche evaluation of energy enterprises and its impact on the selection of ecological strategy based on the data of listed coal mining companies in China, Journal of Shanxi Finance and Taxation College, 18(05), 51-55.

Liu J. (2014), Study on performance evaluation of forest resource management in typical state-owned forest farms. Southwest Forestry University.

Mustafa K., Rizwan Y., Muhammad Z. and Muhammad S. (2019), Treatment of Municipal Waste Water Through Adsorption Using Different Waste Biomass as Activated Carbon, Journal Clean Was, 3(1), 21-27.

Shi B. and Tian H.N. (2018), Research on the path selection of green process innovation in home appliance manufacturing industry based on niche situation, Management Review, 30(02), 83-93.

Suman A. and Md Kutubuddin D. (2020), Longitudinal profiles and geomorphic indices analysis on tectonic evidence of fluvial form, process and landform deformation of Eastern Himalayan Rivers, India, Geology, Ecology, and Landscapes, 4:1, 11-22

Wan L.L. (2004), Study on enterprise niche and its evaluation method, China Soft Science, (01), 73-78.

Xuan L. (2017), The choice of dairy enterprise competitive strategy based on enterprise niche, Inner Mongolia University of Finance and Economics.

Yan A.M. (2006), Research on Evaluation and matching of enterprises and their core employees based on niche theory, Central South University.

Zhang C.H. (2014), Study on the niche evolution of forestry industry in Northeast State-owned forest region, Northeast Forestry University.

Zhang S.Y. (2016), Forest resource management performance evaluation of state-owned forest farms. Agricultural Science and Technology and Information, (13), 149-149.

Zhu C.Q. (1997), Niche situation theory and expansion hypothesis. Journal of Ecology, (03), 324-332.

Zulkapli M.F., Rashid N.M., Mohd Nazri M.S. and Noorshawal N. (2018). Study on Optical Properties of Graphene-Tio Nanocomposite as Photoanodes Layer in Dye Sensitized Solar Cell (Dssc), Environment \& Ecosystem Science, 2(2), 39-41. 